\title{
PROJECT METHOD IN MATHEMATICS. ${ }^{3}$
}

\section{By Byron CosBy}

State Teachers College, Kirksville, Mo.

The term "project method in teaching" has been defined in various ways. It is somewhat like the heuristic method. The primary idea is to develop plans of motivation, and adjust the boy or girl in the search for material into larger or more complex experiences. In attempting to understand the project method, we think of at least four primary definitions: First, to make or construct something as the building of a castle in the history class or a table in the Manual Training Department; Second, to do the thing for pure enjoyment, as going to a show, sketching the landscape or attending a basebell game; Third, to set a problem that provides real situations, as a study of irrigation, dry farming or the building of a house; Fourth, to teach the fundamentals so that the children can appreciate the value of certain facts and experiences of their associates.

In presenting mathematics to the learner, the problem should be stripped of all difficulties due to vocabulary or sentence structure. The child should be taught with the problem, the appreciation of the economic notation, the power and greater independence given through its solution and its place in his world, together with its relation to the world into which he is venturing. This means the child must make use of the information that comes to him in daily life.

When the child recognizes that he has the proper tools for working and some knowledge of and skill in using, he senses the practicality of the subject and attacks the problem. The plan obeys the laws of habits, gives a chance for synthesis as well as analysis, induces the child to associate effort with interest; relieves him of dependency upon textbook and makes him comfortable.

Recently on my way home from work, I was stopped by a small group of men. One was a probate judge, another a Presbyterian minister, and the third a merchant. All of these men were mature, and as the world judges men, they were educated. A problem had attracted their attention. The municipality was extending its lighting system. The workmen had left a piece of apparatus with two wires attached as though the work was completed. One of the men asked me what it was for. I had no answer. The problem held an interest and they did as the adult

tRead before the Mathematics Section of the C. A. S. and M. T, at Soldan High Dehool 8t. Iouts, Mo., November 25, 1921. 
mind so often does, consulted someone else. We called a neighbor, who in early life had been an engineer, but who for twenty years had been a loan agent, and his answer was as evasive as that of any expert. He said, "I never studied telephony." While we were in this complex situation, a ten-year-old lad came by and said, "What's the comedy?" One of the men replied, "We do not understand why two electric light wires should run to a brace and end." The boy answered, "They do not run to the brace and end. The men have just quit work at that point, and tomorrow they will continue the work and lead the wire back to the generating plant." The man of fifty, educated in the isolated topical plan of yesterday, does not have the power to attack the unknown problem. The adult has learned how to function in his problems of daily life. His problem material covers a very narrow range. In working hours, he knows only the isolated problems of a routine business. In his leisure time, he tries to avoid problems, and failing asks someone else to give the solution. The problem material wherein he functions regularly he does more or Iess well, but usually in a very wasteful manner, because he tries to fit this material into some organized formula. He knows only the mechanical rule. He wants certain pieces of furniture in the living room, other pizces in the library or kitchen, and his working tools at his desk. The healthy boy of ten finds it just as satisfactory to leave his football in the dining room, his riding togs in the library, and his bicycle on the front porch or elsewhere. He is not bound by needless conventions. He is elastic; he has power.

The ten-year-old lad mentioned above has initiative power and has not been isolated by mulling over rules and formulas. His teacher for the past three years has been a mature woman, with a master's degree from the Teachers College, Columbia University, and who knows, (1) that a problem is to be stated in simple terms, both the parts given and the parts required, (2) that appreciation of the problem material presents roads to travel from the beginning to end; and (3) that highly integrated machinery does not have to be set up to solve problems. She does not teach isolated facts, nor rules for assembling them, but rather develops the ability to organize the material needed, the power to attack unknown situations, the value of sustained effort and the beauty of accomplished work. This is what we hope for the project plan. 
Our method may be best illustrated by setting certain problems. In our demonstration work in the elementary school, we chose for one of our problems the building of a house. Each child visited some house in the process of construction, then each made tentative floor plans. The best suggestion was chosen. We discussed the contour of the ground, set our levels, established north-south and east-west lines, and investigated the building material. We computed the cubic contents of excavation, the cost of basement floor, the foundation walls, the floor joists and sills, the studding and all other items that entered into the building. While part of the pupils worked upon the building of the house, others interested themselves in interior decoration and landscape architecture. When the problem was finished, we had complete plans and specifications sufficiently correct to build a house. The more elementary children worked out the problems of window curtain and dining room linen; sometimes using newspapers for patterns.

The problem was democratic in that every child had a chance to contribute his information. He had a chance to develop his originality, exercise his social instincts and to obey the motive of conquest. The solution of the problem ealled for many days of work, but each child worked in his field of experience and natural promptings. No time was lost in setting up false and artificial machinery, either for form or solution. Each child worked his part of the problem. Many problems of this type are suggested, as "An Ideal Dining Room," "An Efficient Kitchen," "My Budget for a Year," "Corn Clubs," "School Gardens" and "A Passbook for One Acre of Corn."

In the high school, we try to orient our problems. Our first axiom is "that every child has a right to know why the problem has been introduced, where it belongs in our social or industrial organization and its relative value." If the problem cannot stand this test, it is dropped. We do not have a fondness for recreational problems in the class room. My beloved professor at the University taught me graphic representation. with skill and assurance. I learned mechanically how to find the maxima, mimima, intercepts on $\mathrm{Y}$-line and $\mathrm{X}$-line and the points of inflection. I was able to graph equations with speed and skill, but if he told me the lesson or the function of the graph, I never learned it or else have forgotten his teaching.

I do not understand why our writers of algebra do not introduce graphic representation with a study of the location of 
geographic points by latitude and longitude, with the equator and prime meridian instead of $\mathrm{X}$-and $\mathrm{Y}$-lines; or the units of measure, township and range, with the base line and principal meridian or again the simple problem of locating school, church or home on the town map. Every child in a Missouri high school knows the problem of latitude and longitude; the problem of range and township and how to locate a house by street and number. A statement concerning the parabolic reflector of the railway engine and motor car, of the path of a projectile or falling body gives life to the study of the parabola.

In geometry, the work should presuppose a problem that is needed in the community's life, and geometric principles the working tools for its solution. Proportion helps us to read maps, measure inaccessible distances, and determine our possibilities. Internal tangents give us the problem of belts for change in direction of motion, the parallel lines of proper spacing for pictures or dressmaking, and the idea of tangents for laying out beautiful walks. The golden section problem helps in picture making and interior decoration. Symmetry finds its use in architecture, dress, and analagous argument. The geometric prineiple that areas are proportional to the squares of their corresponding line measurements is found in the problems of sewers, water systems, heating plants, and land drainage. Geometry should be a tool for measuring life, and as such it rarely meets the syllabi so often published.

The advaneed mathematies gives great opportunity. All types of investments call for the solution of standard equations. Why clothe logarithms in mechanically artificial problems when we have annuities, amortization, valuation of bonds, sinking funds and depreciation, building and saving associations, the theory of probability and problems in life insurance. Some of the problems of the ealculus might be replaced by commecial problems; (1) because we might have as great a future need for commercial solutions as for engineering results, (2) I believe the problem of amortization might be as valuable to the average college student, not the mathematical genius or engineering expert, as "assuming that the values of diamonds are proportional, other things being equal, to the squares of their weights, and that a certain diamond which weighs one carat is worth $\$ m$ show that it is safe to pay at least $\$ 8 m$ for two diamonds which together weigh 4 carats, if they are of the same quality as the one mentioned." 
Problems in engineering offer many projects. The manufacturing of cans or the building of roads sets a motive that can be easily handled by such mathematical tools as maxima, minima, and points of inflection. For example:

When a road, railroad, or canal is built, the center line is laid out on the ground. The drives of the park system of Chicago are evidently successive arcs of varying radii. Railroad curves are ordinarily smooth curves. In Raymond's Plane Surveying, one finds a method for locating ares approximately by use of the tape.

We make no infallible claim for any method. A poor plan in the hands of a hardworking, painstaking teacher who is definitely interested in the plan may produce good results. The project plan sets a problem in the field of life where found and puts upon teacher, child, and community the demand to read catalogs, magazines, newspapers, to rely upon self, to consult neighbors and to organize material. It requires of the student only what he is ready for, and gives him just what he asks for. It is demoeratic, in that each child can contribute to the social group, and is honest in that he always works for his ideal and desire and not the artificial findings of some one else. It is not a good plan for the lazy teacher or he whose idol is a texthook. $I$ believe in interest, and effort, and feel that the project method will succeed in the hands of one who wants to work.

\section{GROUP TEACHING IN GEOMETRY.}

By Myrtle Downing

High School, Salina, Kans.

Due to the fact that so many boys and girls are attending our high schools today, which necessarily involves a great variety of mentalities, it is essential that we change our technique of teaching. If we expect good quality of work we must necessarily vary the quantity. We must agree that thoroughness is a moral asset as well as an educational one.

Going on the theory-and this is not theory alone-that a miscellaneous group will arrange itself roughly into three groups; the brilliant, the mediocre, and the dull students, the former plan of giving the same assignment to all pupils leads to one of the following results. If the assignment is made to fit the needs of the bright students, the mediocre students do not get anything well, in their effort to do as much work as the bright ones, and the dull students, which comprise about one-fourth the 